\title{
Recognition of Endogenous Ligands by C-Type Lectins:Interaction of Serum Man- nan-binding Protein with Tumor-associated Oligosaccharide Epitopes
}

\author{
レクチンによる内因性リガンドの認識 : 血清マンナン結合タンパク質と \\ 腫瘍関連糖鎖エピトープの相互作用
}

\author{
Kawasaki, Nobuko; and Kawasaki, Toshisuke \\ Research Center for Glycobiotechnology, Ritsumeikan University, Shiga 525-8577, Japan \\ FAX: 81-77-561-3496,E-mail:tkawasak@fc.ritsumei.ac.jp
}

(Received on May 7, 2010, accepted on May 15, 2010)

Key Words: C-type lectin, Mannan-binding protein, cancer-associated antigen, innate immuninity

\begin{abstract}
Animal lectins have contributed greatly to understanding of the physiological significance of glycans in man and animals. Mannan-binding protein (MBP) binds to mannose, $\mathrm{N}$-acetylglucosamine and L-fucose via the carbohydrate binding sites in its carbohydrate recognition domain (CRD). In pathogenic microorganisms, manno-oligosaccharides on the cell surface appear to be the major glycans involved in the interaction with MBP, whereas in human colorectal carcinoma SW1116 cells, which are endogenous target cells of MBP, Lewis (Le)-type oligosaccharides with the type I structure appear to play a major role in the interaction with the lectin. In fact, MBP ligand oligosaccharides (MLO), which have complex type $\mathrm{N}$-glycans with at least 4 Fuc(Hex-HexNAc) units, have been isolated with an MBP affinity column, whereas complex type $\mathrm{N}$-glycans having 3 or less Fuc(HexHexNAc) units as well as high-mannose type structures (Man5 to Man8) did not bind to the MBP affinity column. The structures of MLO are very unique and distinct from those of other previously reported tumor-specific carbohydrate antigens, and thus should be considered as representative of a new family of tumor-associated carbohydrate antigens. The reasons why and how MLO exhibits such strong affinity to MBP are not clear at present but computer modeling suggested the possibility that a MBP-Lewis oligosaccharides complex may be formed between the trimeric structure of the carbohydrate recognition domain (CRD) and $\mathrm{Le}^{\mathrm{b}}-\left(\mathrm{Le}^{\mathrm{a}}\right)_{\mathrm{x} 4}-\mathrm{Le}^{\mathrm{x}}$, a typical example of the nonreducing terminal oligosaccharide structure of MLO.
\end{abstract}

要 約

動物レクチンはヒトや動物に含まれる糖鎖の生理的役割 の解明に大きく貢献してきた。マンナン結合タンパク質 (MBP) は、その糖鎖認識ドメイン (CRD) に存在する糖結合部位を介 してマンノース、N-アセチルグルコサミン、L- フコースに結 合する。病原微生物では、細胞表層のマンノオリゴ糖が MBP に結合する主要な糖鎖である。これに対し、内在性の標的で あるヒ卜結腸癌細胞株 SW1116 の場合、I 型のルイス型オリ ゴ糖鎖が MBP の主要な結合相手となる。すなわち、SW1116 細胞の可溶化物オリゴ糖鎖を MBP カラムにかけると、4 個以 上の Fuc(Hex-HexNAc) ユニットをもつ複合型糖鎖 (MLO) が カラムに結合するのに対して、3 個以下の Fuc(Hex-HexNAc) ユニットを持つ複合型糖鎖および高マンース型糖鎖 (Man5 to Man8) はMBP カラムに結合しない。これらの結果は、MLO がこれまで報告のない新規な癌関連糖鎖であることを示して いる。なぜ MLO がこのように高い親和性を示すのか、今後の 研究課題であるが、コンピュータモデリングによると MBP の 3 量体と $\mathrm{Le}^{\mathrm{b}}-\left(\mathrm{Le}^{\mathrm{a}}\right)_{\mathrm{x} 4}-\mathrm{Le}^{\mathrm{x}}$ 糖鎖の間に興味深い複合体の形成が可 能なことが示されている。

\section{A. Introduction}

In retrospect, the last few decades have been devoted to revealing the "raison d'etre" of glycans in life
A. 序

振り返ってみると、糖鎖の研究は、これまでの数十年間、 地球上の生命に扔ける“糖鎖の存在意義”を明らかにするた

Abbreviations: CRD, carbohydrate-recognition domain; Hex, hexose; HexNAc, $N$-acetylhexosamine; Le ${ }^{\mathrm{a}}$, Lewis a; $^{\mathrm{b}}{ }^{\mathrm{b}}$, Lewis $_{\mathrm{b}}$; Le ${ }^{\mathrm{x}}, \mathrm{Lewis}_{\mathrm{x}}$; $\mathrm{mAb}$, monoclonal antibody; MBP, mannan-binding protein; MLO, MBP-ligand oligosaccharides. 
on earth by studying their structures, biosynthesis and the functions. Carbohydrate-binding proteins in animals (animal lectins) comprise a family of proteins that play key roles in establishing the biological significance of glycans by mediating the specific recognition of glycans in various situations in vital phenomena.

Studies on animal lectins started in the late 1970s with the isolation of a hepatic lectin in Dr. Gilbert Ashwell's laboratory $(1,2)$. This hepatic lectin is galactose-specific and functions as a receptor for carbohydrate-mediated endocytosis by hepatocytes. A few years later the second hepatic lectin, which is specific for $\mathrm{N}$-acetylglucosamine, was isolated from chicken liver (3). These lectins require calcium for their binding and are designated as C-type lectins (4). With this background, a systematic investigation was carried out to find a third hepatic lectin specific for mannose, since Sia-Gal-GlcNAcMan is a common sequence at the non-reducing ends of $N$-linked glycans. After a number of trials, we discovered the third hepatic lectin in rabbit liver, which we called mannanbinding protein (MBP), since it was isolated successfully with an affinity column of yeast mannan taking advantage of the calcium dependency of its sugar binding activity (5). However, it was soon realized that MBP is a soluble protein and not a transmembrane protein like the first two hepatic lectins. In addition, to our surprise, a mannan-binding protein was detected in rabbit serum during the course of the preparation of antibodies toward rat liver MBP by injecting it into a rabbit (6). MBP isolated from the liver is called L-MBP and that from serum is called S-MBP. They are encoded by separate genes
め、その構造、生合成、機能に関して、進められてきた。動 物体内に含まれる糖結合タンパク質は、動物レクチンと呼ば れ、重要な生命現象の様々な局面において特定の糖鎖の認識 を仲介することにより、糖鎖の生物学的意義を確立する上で 重要な役割を果してきた。

動物レクチンの研究は、1970 年代後半 Gilbert Ashwell 研 究室 $(1,2)$ におけるウサギ肝臓からのレクチンの分離で開始さ れた。このレクチンは、ガラクトースを特異的に認識する膜 貫通タンパク質であり、肝細胞による糖媒介エンドサイトー シスの受容体である。その後間もなく、N-アセチルグルコサ ミンに特異的な 2 番目の肝レクチンが鶏の肝臓より単離され た(3)。これらのレクチンは結合にカルシウムを必要とすると ころから C 型レクチン (4) と総称されている。このような背景 のもと、筆者らは、Sia-Gal-GlcNAc-Man が $N$ - 結合型糖鎖の非 還元末端に共通のシーケンスであるところから、3 番目の肝レ クチンとしてマンノースに特異的なレクチンの存在を想定し て、体系的な探索を始めた。やがて、酵母マンナンを固定化 したアフィニティーカラムを作成し、結合のカルシウム依存 性を利用することにより、ウサギの肝臓より 3 番目の肝レク チンを単離することに成功し、これを、マンナン結合タンパ ク質 $(\mathrm{MBP})$ と名付けた (5)。しかし、その後 $\mathrm{MBP}$ は、先の 2 つの肝レクチンのような膜貫通タンパク質ではなく、可溶性 タンパク質であることが判明した。さらに、ラット肝臓 MBP に対する抗体の作成の過程で、驚いたことに、肝臓に加えて ウサギの血清中にも MBP が存在することを見出した (6)。肝 臓からのレクチンをL-MBP、血清からのものを S-MBP と呼

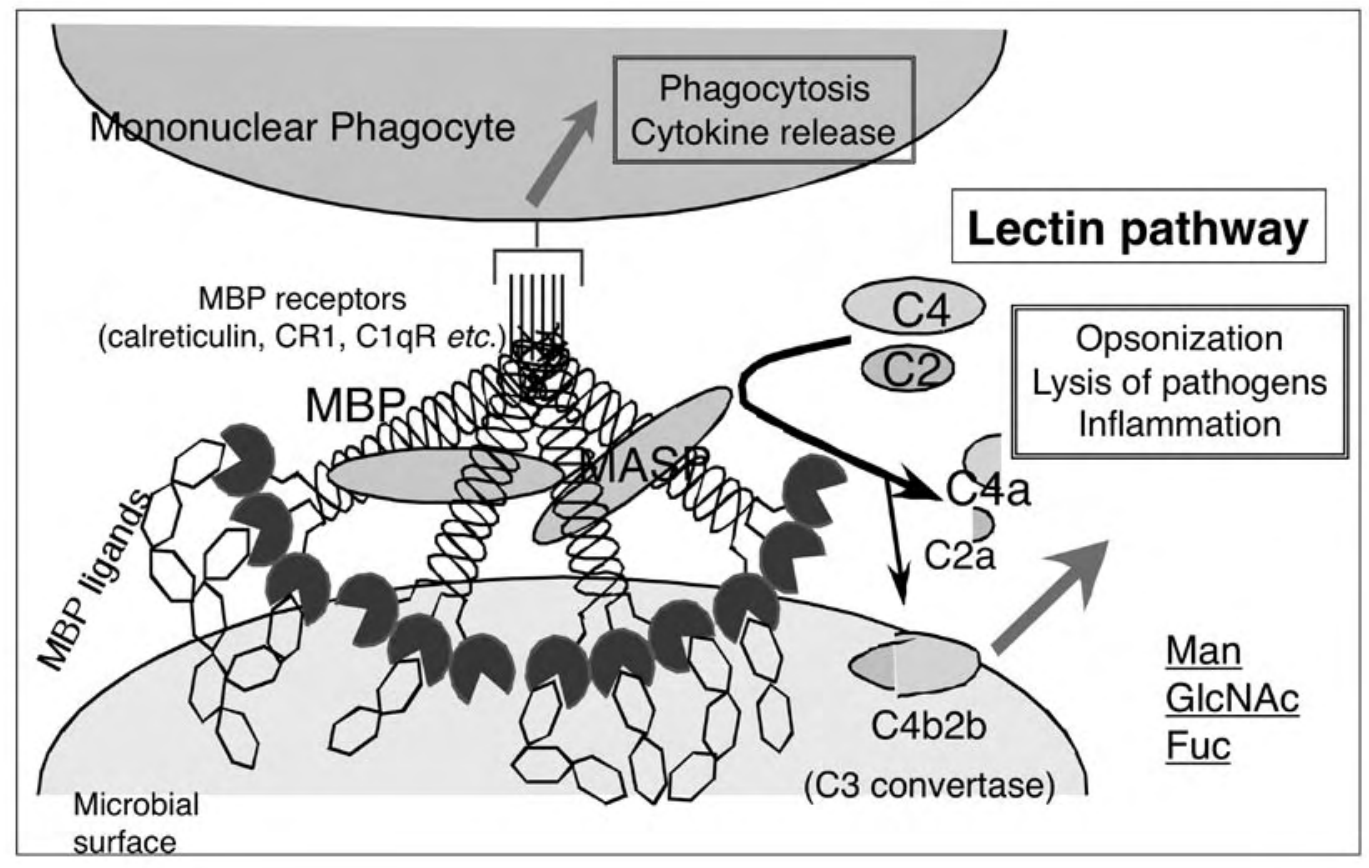

Fig. 1. Host defense functions of the mannan-binding protein. This figure is cited, with slight modifications, from Ref. 25. 
(MBL2 and MBL1, respectively) in mouse (7), rat (8), rhesus monkey (9), and pig (10). On the other hand, only a single cDNA has been cloned for man $(11,12)$, cow (13), rabbit (14), and chicken (15). It should be noted that despite the presence of a single message, almost equal amounts of MBP proteins were isolated from human liver and serum, respectively (16). These two MBP proteins can be distinguished as to the degree of oligomerization through disulfide bonds $(16,17)$, which occurs as a post-translational modification. The following studies demonstrated that S-MBP plays a pivotal role in host defense, particularly in the innate immune system, such as in complement activation via the lectin pathway (18-25) (see Fig.1) and tumor cell recognition (26), while L-MBP (or I-MBP) appears to serve as a cargo receptor in the intracellular transport of glycoproteins (27-29). In this review article, we would like to discuss the sugar binding specificity of S-MBP with regard to tumor cell recognition.

\section{B. Oligomer Structure and Carbohydrate Recognition Domain (CRD) of MBPs}

MBP is a homo-oligomer of a $\sim 31 \mathrm{kDa}$ subunit, each subunit containing a carbohydrate recognition domain (CRD) of $\sim 115$ amino acids in its $\mathrm{COOH}$-terminal domain, followed by a short neck region and a collagen-like domain, which consists of 18-20 Gly-Xaa-Yaa repeats, followed by a short amino-terminal region (cysteine-rich region) (30). Three subunits form a structural unit, and S-MBP normally consists of 3-6 structural units $(21,22)$ joined through disulfide bonds at their amino termini, the total molecular mass being 300-600 $\mathrm{kDa}(31)$, whereas L-MBP consists mainly of 2 structural units (32). Lines of evidence indicate that a high degree of MBP oligomerization is required for the activation of complement $(22,31)$. The lectin bind to mannose, $N$-acetylglucosamine and L-fucose $(33,34)$ via the carbohydrate binding sites in the CRD (35). It should be noted, however, that the lectin binding affinity to any kind of monosaccharide is not high enough for in vivo recognition. Biologically significant binding can be demonstrated to occur only to high molecular weight ligands with multiple mono- or oligosaccharides on a high-molecular weight carrier molecule. This mode of recognition appears to be common to most animal lectins, being particularly remarkable for MBP, and is called the cluster effect (36) or pattern recognition (37).

\section{Isolation and Characterization of Tumor-Associated Oligosaccharide Ligands for S-MBP}

The most unique characteristic of this host defense system is the distinction of pathogenic microorganisms from the host cells due to nature of their cell surface carbohydrates. MBP binds to manno-oligosaccharides, which are frequently the natural ligands on pathogenic microorganisms,
んだ。マウス (7)、ラット (8)、アカゲザル (9)、ブタ (10) などでは、 これらの MBP はそれぞれ別の遺伝子 $(M B L 2$ と $M B L 1)$ により

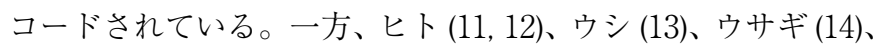
ニワトリ (15) では一種類の cDNA しか検出されていない。ヒ トでは 1 つの MBP 遺伝子 $(M B L 2)$ の産物であるにもかかわら ず, 肝臟掞よび血清から、ほぼ同じ量のタンパク質が単離され る (16)。これら 2 つの MBP は翻訳後修飾の過程で生じるジス ルフィド結合を介するオリゴマーの形成の度合いが異なる $(16$, 17)。その後の研究により、S-MBP は自然免疫系、特にレクチ ン経路 (18-25) と呼ばれる経路を介して補体系を活性化し、生 体防御に重要な役割を持つこと (図 1 参照)、さらに内在性異 物としての腫瘍細胞を認識することが明らかにされた (26) 一 方、L- MBP(または I-MBP) は糖タンパク質の細胞内輸送 (2729)の積み荷受容体としての機能を持つとされている。このレ ビューでは、S-MBP の糖鎖結合特異性を腫瘍細胞の認識の面 から紹介したい。

\section{B. MBP のオリゴマー構造と糖認識ドメイン (CRD)}

MBP は約 $31 \mathrm{kDa}$ サブユニットのホモオリゴマーである。 各サブユニットはC 末端ドメインに約 115 アミノ酸よりなる 糖鎖認識ドメイン $(\mathrm{CRD})$ を含む。ついで短い頸部、18-20 個 のグリシン -X-Yの 3 アミノ酸の繰り返し構造よりなるコラー ゲン様ドメインが続いて、最後は短いアミノ末端領域(シス テインの豊富な地域) となる (30)。3 個のサブユニットは一つ の構造単位を形成する。S-MBPは通常 3-6 個の構造単位 (21, 22)がアミノ末端でジスルフィド結合により架橋され、全体の 分子量が 300 から $600 \mathrm{kDa}$ を示す (31)。これに対し、L-MBP は 2 個の構造単位 (32) で構成されている。一連の研究により、 S-MBP による補体系の活性化には、高度のオリゴマー形成が 必要であることが示されている $(22,31)$ 。本レクチンは CRD の 糖鎖結合部位 (35) を介してマンノース、N-アセチルグルコサ ミンおよびL-フコースと結合する (33,34)。しかし、それはそ れぞれの単糖がそれ自身、レクチンに結合するのに十分に高 い親和性を持つということではない。生体認識において有効 な高親和性の結合は、複数の単糖やオリゴ糖が高分子キャリ ア分子上に配置された場合にのみ観察されてる。このような 認識の仕組みは、多くの動物レクチンに共通と思われるが、 特にMBP の場合に顕著に示されており、クラスター効果 (36) あるいはパターン認識 (37) と呼ばれている。

\section{S-MBP による癌関連糖鎖リガンドの単離とその性質}

この生体防衛システムのユニークな特徴は、細胞表面の 糖鎖の性質によって宿主細胞から病原微生物を区別すること である。MBP は病原微生物表面に頻繁に見られる自然リガン ドであるマンノオリゴ糖鎖と結合する。これに対し、哺乳類 
whereas most mammalian cells are covered with complex oligosaccharides with sialic acids at their non-reducing termini, which precludes the binding of MBP to the cells. However, we and others previously noticed that MBP binds to some human tumor cell lines, suggesting the possibility that MBP also functions as a defense factor against abnormal cells produced in host animals $(38,39)$. In a subsequent study, we demonstrated that the vaccinia virus carrying the human MBP gene exhibited potent growth inhibitory activity toward human colorectal carcinoma SW1116 cells in nude mice via a complement-independent mechanism. We proposed calling this activity MBP-dependent cellmediated cytotoxicity (MDCC) (26). In order to elucidate the mechanism of interaction between MBP and tumor cells, the presumptive MBP ligands on the surface of SW1116 cells were characterized. Initial experiments involving plant lectins as inhibitors of MBP binding to SW1116 cells indicated that AAL (Aleuria aurantia lectin), a Fuc-binding lectin, inhibited the binding strongly, whereas Con A (Concanavalin A) and LCA (Lens culinaris agglutinin), Man-binding lectins, did not inhibit the binding significantly. Subsequent experiments involving anti-Lewis (Le) antibodies as inhibitors indicated that anti-Le $e^{b}$ mAbs inhibited the binding most effectively and dose-dependently, followed by anti-Le ${ }^{\mathrm{a}} \mathrm{mAbs}$, whereas anti$\mathrm{Le}^{\mathrm{x}}$ and anti-Le $\mathrm{y}^{\mathrm{y}} \mathrm{mAbs}$ did not inhibit the binding significantly. These results indicated that manno-oligosaccharide structures are not associated with tumor recognition and, instead, fucosecontaining oligosaccharides, in particular type I sugar chains, play crucial roles in the tumor recognition by MBP.

To understand in more detail the properties of MBP ligands on the surface of SW1116 cells, we attempted to isolate MBP ligands. Pronase glycopeptides were prepared from whole lysates of SW1116 cells and oligosaccharides were liberated by hydrazinolysis. After being tagged by pyridylamination, PA-oligosaccharides were applied to an MBP affinity column. Approximately $6 \%$ of the PAoligosaccharides bound to the column in the presence of calcium and were eluted with EDTA. This was a big surprise for us in view of the fact that there had been no report of the successful isolation of oligosaccharides with an MBP affinity column, suggesting that the isolated oligosaccharides should have some characteristic structural features as to their high affinity to an MBP column. The isolated fraction was called MBP ligand oligosaccharides (MLO), and the sequences of the MLO were determined by mass spectrometry (40). First, we estimated the sizes of the ligand oligosaccharides by MALDIMS after permethylation. A cluster of signals was observed between $\mathrm{m} / \mathrm{z} 4200$ and 9000 , the average being 6200, and throughout this region, peaks of materials differing by a Fuc or Fuc-(Hex-HexNAc) unit difference were observed. The $m / z$ 9000 peak corresponds to 13 repeats of Hex-HexNAc with 11
細胞は一般に複雑な糖鎖で覆われており、その非還元末端は ほとんどの場合、シアル酸に覆われている。このため、通常 MBP はホス卜細胞へは結合しない。しかしながら、私たちを 始め、他の研究者も以前より、MBPがいくつかのヒト腫瘍細 胞に結合することに気付いており $(38,39) 、 M B P$ が生体内で生 じた異常細胞にたいする生体防御因子として機能する可能性 が指摘されていた。そこで、私達はヌードマウスにヒト結腸 癌細胞株、SW1116 細胞を移植させて作成した腫瘍塊に、ヒ トMBP の遺伝子をワクシニアウイルスに組み込んだ発現ベク ターを注射したところ、腫瘍は急速に退縮することを見出し た。この作用は補体非依存性機構であるところから、我々は この MBP の働きを MBP 依存的細胞性細胞傷害作用 (MDCC) 呼ぶことを提案している(26)。そこで、次に、MBP と腫瘍細 胞との相互作用のメカニズムを知る目的で、SW1116 細胞の 表面に存在が推定される MBPリガンドの特徴を調べた。最初、 MBP の SW1116 細胞への結合に対する植物のレクチンの阻害 効果を調べた。その結果、AAL(ヒイロチャワンタケレクチ ン)、フコース結合レクチン、は強く結合を抑制したのに対し て、ConA(コンカナバリン)と LCA(レンズマメレクチン)など、 マンノース結合レクチンは、ほとんど結合を阻害しなかった。 次に、阻害剤として、種々の抗ルイス抗体の阻害効果を調心゙ たところ、抗 Le $e^{\mathrm{b}}$ 抗体は、最も効果的かつ用量依存的に阻害 を示した。続いて、抗 Le $\mathrm{e}^{\mathrm{a}}$ 抗体により阻害が見られた。一方、 抗 $\mathrm{Le}^{\mathrm{x}}$ 抗体、抗 $\mathrm{Le}^{\mathrm{y}}$ 抗体は、阻害を示さなかった。これらの 結果は、MBPによる腫瘍の認識に打いては、マンノオリゴ糖 構造は関与せず、代わりに、フコースを含むオリゴ糖、中で もI 型の糖鎖に結合したフコース残基が重要な役割を果たし ていることを示していた。

そこで、より詳細にSW1116 細胞表面の MBP リガンド の性質を理解するために、MBPリガンド糖鎖の単離を試み た。まず、SW1116 細胞可溶化物をプロナーゼ消化して糖ぺ プチドを調製し、次いでヒドラジン分解により糖鎖を遊離し た。遊離した糖鎖は、PA(ピリジルアミノ化) 標識したのち、 $\mathrm{PA}$-オリゴ糖を、MBP アフィニティーカラムにかけた。PA - オリゴ糖の約 $6 \%$ はカルシウムの存在下でカラムに結合し、 EDTA で溶出された。この結果は、筆者らに取っては大きな 驚きだった。というのは、これまでにMBP アフィニティーカ ラムによりオリゴ糖を単離したという報告は皆無だったから である。すなわち、この MBPアフィニティーカラムにより単 離されたオリゴ糖鎖は、MBP カラムに高親和性で結合するた めのいくつかの構造的特徵を持っていると考えられた。単離 された画分を MBPリガンドオリゴ糖鎖 (MLO) と呼び、その 糖鎖配列を質量分析法により解析した (40)。まず、完全メチル 化の後、MALDI-MS によりリガンド糖鎖の大きさを推定した。 シグナルピークは $m / z 4200$ と 9000 の間に広く分布し、平均 值は 6200 付近に認められた。さらに、この幅広いピークを通 じて見られるシグナルには、Fuc あるいはFuc(Hex-HexNAc) 単位の規則的な差が認められた。 $\mathrm{m} / z 9000$ のピークは、13リ ピートの Hex-HexNAc と 11 個の Fuc を持つ構造に対応した。 
Fig.2. Proposed structures of MBPligand oligosaccharides (MLO). The MBP ligands on SW1116 cells are mostly composed of tetraantennary core fucosylated $\mathrm{N}$-glycans with highly fucosylated polylactosamine type structures. The overall carbohydrate structures of the neutral and acidic MBP ligands are very similar except at the nonreducing termini. The acidic ligands are capped with sialic acid to form the sialyl Le ${ }^{\mathrm{a}}$ structure. The MBP ligands in SW1116 cells are mostly expressed on the CD26 molecule. This figure is cited, with slight modifications, from Ref. 41.

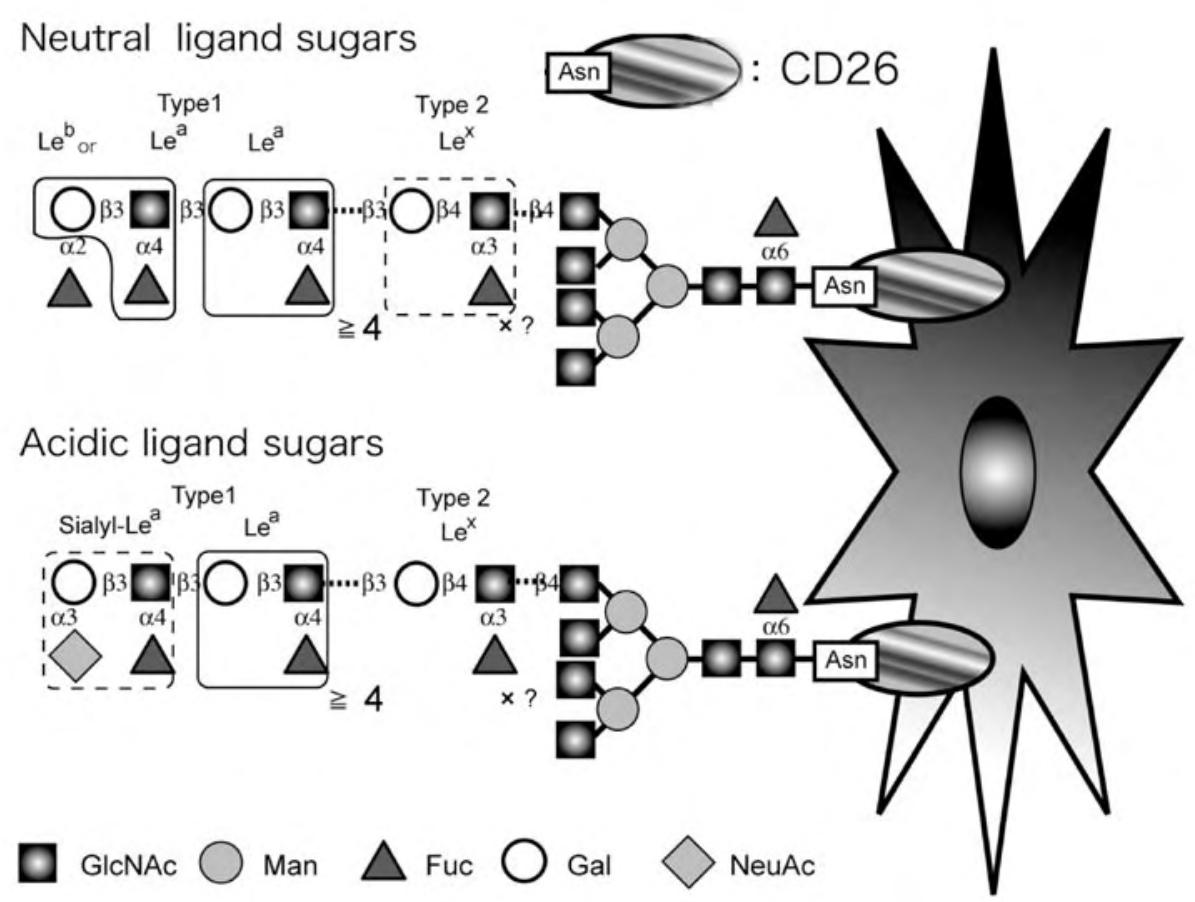

Fuc residues. Analysis of the fragment ions by off-line nanoESI-MS and MALDI-MS indicated the presence of a series of fucosylated, non-reducing terminal fragment ions including up to 5 Hex-HexNAc units. From these results together with those of endo- $\beta$-galactosidase digestion and chemical defucosylation, the sequences of the endogenous MBP ligands were proposed to be as shown in Fig. 2. The ligands are large, multiantennary $\mathrm{N}$-glycans each carrying a highly fucosylated polylactosamine type structure. At their nonreducing termini, $\mathrm{Le}^{\mathrm{b}} / \mathrm{Le}^{\mathrm{a}}$ or tandem repeats of the $\mathrm{Le}^{\mathrm{a}}$ structure prevail, a substantial proportion of which are attached via internal $\mathrm{Le}^{\mathrm{x}}$ or $\mathrm{N}$-acetyllactosamine units to the trimannosyl fucosylated core. The structures of MLO are very unique and distinct from those of other previously reported tumor-specific carbohydrate antigens. First, MLO are present as $N$-glycans, not as glycolipids or $O$-glycans. Second, the tandem repeat region of MLO is much longer than the dimeric or trimeric structure. Third, the tandem repeats consist of the $\mathrm{Le}^{\mathrm{a}}$ structure rather than the $\mathrm{Le}^{\mathrm{x}}$ structure, particularly at or near the nonreducing termini. Because of these characteristics, the MLO should be considered as representative of a new family of tumorassociated carbohydrate antigens (40). With respect to the MBP recognition of $\mathrm{Le}^{\mathrm{a}}$ tandem repeat structures, we have confirmed similar effects on glycolipid specimens isolated from COLO205 cells (42).

\section{Identification of CD26 as a Major MLO Carrier Protein in SW1116 Cells}

In the next experiment, we attempted to identify the
さらに、オフラインナノ ESI-MS およびMALDI-MS による フラグメントイオンの解析では、一連のフコシル化された非 還元末端断片イオン、Hex-HexNAc として5 個までの繰り返 し構造の存在が示された。これらの結果をエンド - $\beta$ - ガラク トシダーゼ消化抒よび化学的フコース除去実験などの結果と 合わせて判断し、MBP のリガンド糖鎖の配列を図 2 に示すよ うに提案した。リガンドは、高度にフコース置換を受けたポ リラクトサミン型の糖鎖をもつ多分岐 $N$ 型糖鎖であった。非

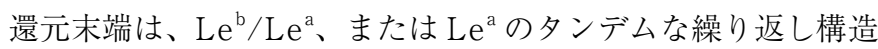
を持つ。その内側はかなりの割合でLex または $N$-アセチル ラクトサミンを介してトリマンノシルフコシルコアユニット に接続している。MLOは非常にユニークな構造で、これまで 報告にある腫瘍特異的糖鎖抗原とははっきりと区別される特 徵を持つ。すなわち、まず、MLO は N 型糖鎖であり、糖脂 質や O 型糖鎖ではない。第二に、 $\mathrm{Le}^{\mathrm{a}}$ のタンデムリピートは 報告のある 2 量体または 3 量体の枠を遥かに超え長い。第三 に、タンデムリピートは $\mathrm{Le}^{\mathrm{x}}$ 構造ではなく、 $\mathrm{Le}^{\mathrm{a}}$ 構造であり、 特に非還元末端付近に含まれる。これらの特性のため、MLO は、従来の腫瘍関連糖鎖抗原とは別に、新規腫瘍関連糖鎖抗 原ファミリーの代表として見なされるべきであろう (40)。な お、MBPによる $\mathrm{Le}^{\mathrm{a}}$ タンデムリピート構造の認識に関しては COLO205 細胞より単離した糖脂質試料について同様の効果を 確認している (42)。

\section{SW1116 細胞の主要な MLO 担体タンパク質としての CD26 分子の同定}

次に SW1116 細胞に含まれる MLO 担体タンパク質の同定 
carrier proteins of MLO in SW1116 cells. Utilizing an MBP affinity column, we succeeded in the isolation of the major MBP-ligand glycoproteins from cell lysates, and identified them as CD26/dipeptidylpeptidase IV (DPPIV) (110 kDa) (43) and CD98 heavy chain (CD98hc)/4F2hc (82 kDa) (44). PNGase $\mathrm{F}$ and endo $\beta$ - $N$-acetylglucosaminidase $\mathrm{H}$ digestion of these proteins together with MBP-blot analysis suggested that CD26 contained complex-type $N$-glycans (MLO) that appear to mediate the MBP binding, whereas the CD98 heavy chain consisted almost exclusively of high-mannose type or hybrid type glycans. MALDI-MS of the $N$-glycans released from $\mathrm{CD} 26$ by PNGase F demonstrated conclusively that CD26 is the major MLO-carrying protein. Thus, the major molecular ion signals observed on MALDI-MS analysis of permethylated $\mathrm{N}$-glycans correspond to a hybrid type $\mathrm{N}$-glycan with 1 Fuc(Hex-HexNAc) terminal, followed by complex type $N$-glycans with 2 Fuc(Hex-HexNAc) termini, and then ones with increasing numbers of Fuc(Hex-HexNAc) termini in multiples of up to six. The majority of the signals appeared to also reflect core fucosylation and a bisecting GlcNAc (42).

\section{E. Characterization of MBP-binding and Non-binding Glycopeptides Derived from CD26}

In subsequent studies, MBP-binding and non-MBPbinding glycopeptides were prepared from chymotrypsin digests of a CD26 sample, and the $\mathrm{N}$-glycans and de- $\mathrm{N}$ glycosylated peptides were analyzed by MS separately. The $\mathrm{N}$-glycan profiles for the non-MBP-binding fraction contained a major signal at $m / z 3460$, corresponding to 3 Fuc(HexHexNAc) units, components with a total of 4-6 Fuc(HexHexNAc) units giving only very weak signals. In contrast, the MBP-binding fraction afforded major signals above $\mathrm{m} / \mathrm{z} 3900$, corresponding to $4 \mathrm{Fuc}(\mathrm{Hex}-\mathrm{HexNAc})$ units, and extending up to about $m / z 6400$, corresponding to 5 to 7 Fuc(Hex-HexNAc) units. This striking pattern demonstrated clearly that glycopeptides derived from CD26 that could bind efficiently to an MBP column carried mostly complex type $N$-glycans with at least $4 \mathrm{Fuc}(\mathrm{Hex}-\mathrm{HexNAc})$ units. As a consequence of these larger glycopeptides being preferentially enriched in the binding fraction, the non-binding fraction in turn contained less of them relative to smaller ones. Conversely, the glycopeptides with bi- and tri-antennary complex type $\mathrm{N}$-glycans were found mostly in the non-binding fraction. It should be further noted that glycopeptides carrying highmannose type structures (Man5 to Man8) were also clearly not MLO, as these glycans were prominently detected only in the non-binding fraction (42). These findings indicate clearly that the mode of recognition of endogenous ligands by endogenous lectins is more highly sophisticated than previously was believed.

The heterogeneity of glycan structures on CD26
を試みた。SW1116 細胞の可溶化物をMBP カラムにかけ、主 要な MBPリガンド糖タンパク質の分離に成功した。それらは CD26/dipeptidylpeptidase 4(DPPIV)(110 kDa)(43) およびCD98 重鎖 (CD98hc)/4F2hc(82 kDa)(44) と同定された。PNGase F 消化物およびエンド $\beta-N$ - アセチルグルコサミニダーゼ H 消 化物を MBP ブロットで解析することにより、CD26 分子は、 MBP との結合を仲介する複合型 N 型糖鎖 (MLO) を含んでい るが、CD98 重鎖はほぼすべて高マンノース型またはハイブ リッド型糖鎖よりなることが示された。さらに、CD26 分子 の PNGase $\mathrm{F}$ 処理により遊離した $N$ 型糖鎖を MALDI-MS 分 析することにより CD26 分子が主要な MLO 担体タンパク質で あることを確認できた。すなわち、完全メチル化 $N$ 型糖鎖を MALDI-MS 分析したところ、主要な分子イオンシグナルは、 1 Fuc(Hex-HexNAc) 末端を持つハイブリッド型 $N$ 型糖鎖であ り、次いで 2 Fuc(Hex-HexNAc) をもつ複合型 $N$ 型糖鎖、そして、 最大 6 Fuc (Hex-HexNAc) まで続く複合型 $N$ 型糖鎖に対応した。 また、シグナルの大部分はコアフコースおよびバイセクティ ング GlcNAcの存在を示唆していた (42)。

\section{E. CD26 分子から得られた MBP 結合画分と MBP 非結合画分 の性質}

次に、CD26 分子のキモトリプシン消化物を MBP カラ ムにかけると結合画分と非結合画分に分離した。それぞれの 画分について、 $N$ 型糖鎖の構造と $N$ 型糖鎖を遊離させた残り のペプチド部分の構造をMSにより解析した。MBP 非結合 画分の $N$ 型糖鎖は 3 Fuc(Hex-HexNAc) に対応する $m / z 3460$ に主要なシグナルを与え、4-6 Fuc(Hex-HexNAc) に相当する 部分には非常に弱いシグナルが見られたにすぎなかった。一 方、MBP 結合画分は対照的に 4 Fuc(Hex-HexNAc) に対応す る $\mathrm{m} / \mathrm{z} 3900$ に主要なシグナルを与え、5-7 Fuc(Hex-HexNAc) に対応する $m / z 6400$ までシグナルが観察された。この印象的 なパターンは明らかに MBP カラムに結合する CD26 分子の 糖ぺプチドは、ほとんどすべてが少なくとも 4 個の Fuc(HexHexNAc) を持つ複合型糖鎖を含むことを示している。これ らの大きな糖鎖が選択的に MBP 結合画分に回収される結果、 MBP 非結合画分では、小型糖鎖に比べてこれらの大型糖鎖は 少なくなる。逆に、bi- 昖よび tri-アンテナ型の複合型 $N$ 型糖 鎖はほとんどすべてが MBP 非結合画分に回収された。また、 高マンノース型糖鎖 (Man5-Man8) はほとんどすべてが MBP 非結合画分に回収されており、明らかに MBP との結合性は弱 いことが明らかとなった (42)。以上の結果は内在性レクチンに よる内在性リガンドの糖鎖認識が従来考えられていた以上に 高度に制御されたものであることを示している。

$\mathrm{CD} 26$ 分子の糖鎖構造に著しい不均一性が見られので、次 
molecules prompted us to study the distribution of binding and non-binding glycans at the respective glycosylation sites. Thus, the PNGase F-treated (de- $N$-glycosylated) peptides in the binding and non-binding fractions were subjected to automated nanoLC-ESI-MS/MS analyses separately and the resulting MS/MS data were matched with the $\mathrm{CD} 26$ protein sequence by means of a Mascot search. The PNGase F-treated peptides carrying NXS/T sites all exhibited conversion of Asn to Asp, with a mass increment of 1 unit. The results obtained indicated that 7 out of the 9 potential sites were originally $\mathrm{N}$-glycosylated and the high affinity MLO were expressed preferentially at some $N$-glycosylation sites, but this site preference was not so stringent (42).

\section{F. Computer Modeling of the Tandem Repeat Structure of $\mathrm{Le}^{\mathrm{a}}$ Oligosaccharides and the MBP-Lewis Oligosaccharides Complex}

The observations that the MBP column-binding glycopeptides carried mostly complex type $N$-glycans with at least 4 Fuc(Hex-HexNAc) units, while the non-binding fraction contained $N$-glycans with 2 or 3 Fuc(Hex-HexNAc) units and ones with high-mannose type structures suggested the possibility that $4 \mathrm{Fuc}(\mathrm{Hex}-\mathrm{HexNAc})$ units may have a certain unique conformation preferable for high affinity binding to MBP. Computer modeling suggested the possibility that the tandem repeat structure of the Le $e^{a}$ unit can form a right-handed helix in which equivalent positions recur every 8 $\mathrm{Le}^{\mathrm{a}}$ units, as shown in Fig. 3A. In addition, as can be seen on
に、それぞれの糖鎖付加部位について、結合型糖鎖と非結合 型糖鎖の分布を検討した。すなわち、結合型画分と非結合型 画分の糖ペプチドをPNGase F で 処理した後、自動 nanoLCESI-MS/MS 分析にかけ、得られた MS / MS データをマスコッ 卜検索によるCD26 分子のタンパク質に対する配列と比較検 討した。NXS/T を含むぺプチドを PNGase F 処理すると Asn がAsp に変換するため、1 ユニットの質量の増加が見られる。 その結果、9 個の潜在的な $N$ 型糖鎖結合部位の内、7箇所で実 際に糖鎖修飾が観察された。またある部位では優先的に高親 和性糖鎖 MLO の存在が見られたが、この部位選択性はそれほ ど厳密ではなかった $(42) 。$

F. Le $e^{a}$ のタンデム繰り返し構造と MBP - ルイスオリゴ糖鎖複 合体のコンピュータモデリング

MBP カラム結合性画分には少なくとも 4 つの Fuc(HexHexNAc) 単位をもつ $N$ 型糖鎖が含まれているのに対して、非 結合性画分には、2-3Fuc(Hex-HexNAc) 単位を含む複合型 $N$ 型糖鎖掞よび高マンノース型糖鎖が含まれている。これらの 結果は、4Fuc(Hex-HexNAc) ユニットは、MBPに結合するに 望ましい特定の立体構造を持つことができることを示唆して いるようにも思われる。コンピュータモデリングによりこの 点を検討した。その結果、 $\mathrm{Le}^{\mathrm{a}}$ のタンデム繰り返し構造は、8 個の $\mathrm{Le}^{\mathrm{a}}$ ユニットごとに同等の位置にもどる右巻きらせんを 形成することが示唆された (図 $3 \mathrm{~A}$ )。また、 $\mathrm{Le}^{\mathrm{a}}$ aヘリックス
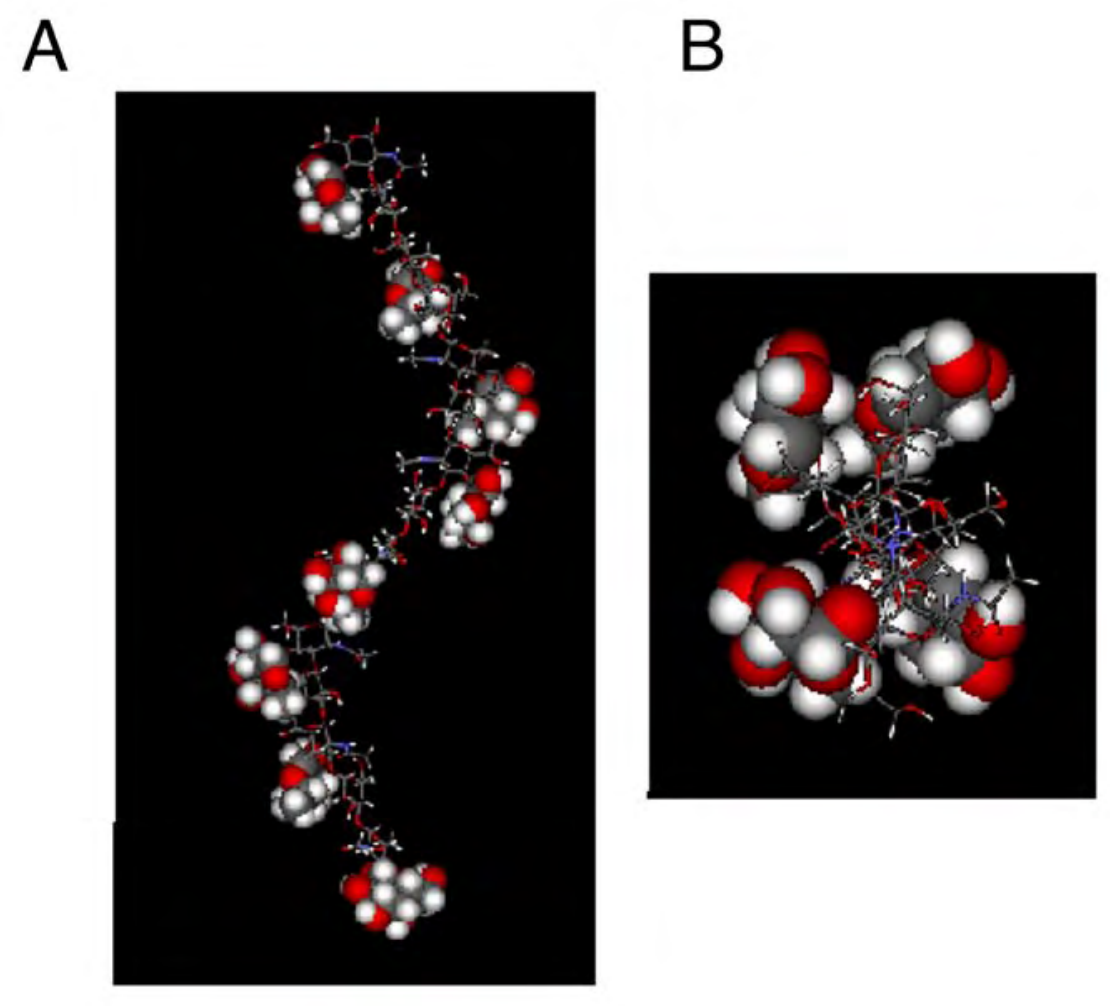

Fig. 3. 3D model of tandem repeats of the $\mathrm{Le}^{\mathrm{a}}$ unit. A, Side view of a right-handed helix of eight tandem repeats of the $\mathrm{Le}^{\mathrm{a}}$ unit. The tandem repeat structure of the $\mathrm{Le}^{\mathrm{a}}$ unit can form a right-handed helix in which equivalent positions in the helix recur every 8 tandem repeats. The structure is depicted as a balland-stick model except for L-fucose, which is shown as a CPK model; B. View from the top of the four tandem repeats of the $\mathrm{Le}^{\mathrm{a}}$ unit. The lower left fucose faces the front and the lower right fucose is the most remotely located. These figures are cited, with slight modifications, from Ref. 42. 

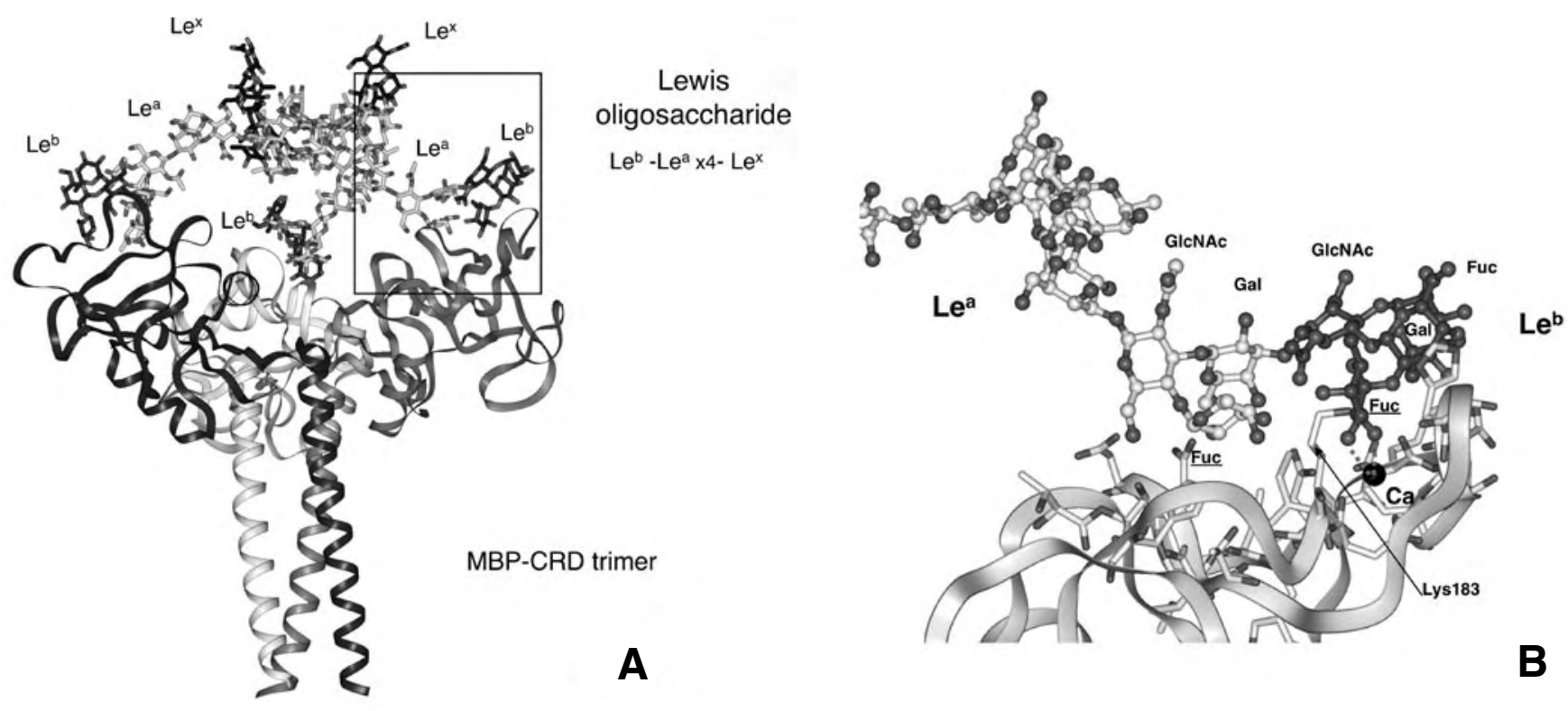

Fig. 4. 3D model of the MBP-Lewis oligosaccharide complex. A, 3D model of the trimeric MBP-Lewis oligosaccharide complex. The crystal structure of the trimeric mannan (mannose)-binding protein (pdb code: 1kww) was used to build the complex model with the oligosaccharide fragment. The ribbon model of an MBP-trimer is represented by light gray, dark gray, and black ribbons, and the Lewis oligosaccharides by ball and stick models. Le ${ }^{\mathrm{b}}$ : dark gray balls and sticks, Le ${ }^{\mathrm{a}}$ : light gray balls and sticks, Le ${ }^{\mathrm{x}}$ : black balls and sticks; B, Close-up view of the area corresponding to the boxed area in A. White sticks represent amino acids. A Ca ion interacts with L-Fuc in Le ${ }^{\mathrm{b}}$ (dark gray). L-Fuc in Le ${ }^{\mathrm{a}}$ (light gray) adjacent to the terminal Le ${ }^{\mathrm{b}}$ may also interact at the $2 \mathrm{nd}$ site with Lys183 (black arrow) and Asp184 (not shown). These figures are cited, with slight modifications, from Ref. 41.

viewing of the $\mathrm{Le}^{\mathrm{a}} \alpha$ helix from the top, fucose residues extend away from the long axis of the chain and every fourth fucose residue recurs at an equivalent position (Fig. 3B). This unique topology of fucose residues in the $\mathrm{Le}^{\mathrm{a}} \alpha$ helix may be relevant as to the high affinity binding of MLO to MBP (41).

Fig. 4A presents a model of the MBP-Lewis oligosaccharides complex between the trimeric structure of the carbohydrate recognition domain (CRD) and $\mathrm{Le}^{\mathrm{b}}-\left(\mathrm{Le}^{\mathrm{a}}\right)_{\mathrm{x} 4}-\mathrm{Le}^{\mathrm{x}}$, a typical example of the non-reducing terminal oligosaccharide structure of MLO (see Fig. 2). Of the two Fuc residues in the $\mathrm{Le}^{\mathrm{b}}$ unit, the one in the $\mathrm{Le}^{\mathrm{a}}$ unit appears to contribute to the protein binding via a calcium ion, and the other fucose residue in the penultimate $\mathrm{Le}^{\mathrm{a}}$ unit feasibly interacts with Lys183 and Asp184 in the MBP molecule (Fig. 4B). In addition, the binding of each oligosaccharide chain to the trimeric protein structure resulted in the formation of a bundle of three oligosaccharide chains with fucose-fucose and galactosegalactose interactions in the three $\mathrm{Le}^{\mathrm{a}}$ units at the $\mathrm{Le}^{\mathrm{x}}$ end. Since the bundle formation occurred in the $\mathrm{Le}^{\mathrm{a}}$ unit at the $\mathrm{Le}^{\mathrm{x}}$ end, the five tandem structure of the $\mathrm{Le}^{\mathrm{a}}$ units (or four $\mathrm{Le}^{\mathrm{a}}$ and one $\mathrm{Le}^{\mathrm{b}}$ unit) appears to be important for bundle formation (42).

\section{G. Perspective and Future Directions}

Revealing the modes of recognition of natural or endogenous ligand glycans by animal lectins provides a critical clue for understanding the functions of glycans in
を上から見ると、フコース残基は長軸から離れて飛出したよ うな場所に位置し、また、すべての 4 番目のフコースは同等 の位置に有ることが分った(図 3B)。L $\mathrm{Le}^{\mathrm{a}} a$ ヘリックスにおけ るフコースのこのユニークなトポロジーは、MBPに対して高 親和性の結合を示す理由と関連するものかも知れない (40)。

図 4A は、MBP の糖鎖認識ドメイン (CRD)の 3 量体と ルイス糖鎖 $\mathrm{Le}^{\mathrm{b}}-\left(\mathrm{Le}^{\mathrm{a}}\right)_{\mathrm{x} 4}-\mathrm{Le}^{\mathrm{x}}$, との複合体モデルを示しています。 $\mathrm{Le}^{\mathrm{b}}-\left(\mathrm{Le}^{\mathrm{a}}\right)_{\mathrm{x} 4}-\mathrm{Le}^{\mathrm{x}} 、$ は、代表的な MLO の非還元末端の糖鎖構造 ( 図 2 参照)です。 $\mathrm{Le}^{\mathrm{b}}$ ユニットの 2 つのフコースの内、 $\mathrm{Le}^{\mathrm{a}}$ ユニッ トのフコースがカルシウムイオンを介するタンパク質との結 合に関与してる。また、最後から 2 番目の $\mathrm{Le}^{\mathrm{a}}$ のフコース残 基もMBP の Lys183 と Asp184 との相互作用 (図 4B)に関与 している可能がある。さらに、各ルイスオリゴ糖鎖が 3 量体 タンパク質に結合すると、3つのルイスオリゴ糖鎖の $\mathrm{Le}^{\mathrm{x}}$ 末端 の隣の 3 個の $\mathrm{Le}^{\mathrm{a}}$ ユニットの間にフコースとフコース、ガラ クトースとガラクトースの相互作用が働き、その結果、3つの 糖鎖ユニットが束を形成すると考えられる。束形成には 5 つ の $\mathrm{Le}^{\mathrm{a}}$ タンデムユニット (または 4 つの $\mathrm{Le}^{\mathrm{a}}$ と 1 つの $\mathrm{Le}^{\mathrm{b}}$ 単位) が重要であることが示されている (42)。

\section{G. 展望と今後の方向}

動物レクチンによる天然のリガンド糖鎖や内因性のリガ ンド糖鎖の認識のモードを明らかにすることは、糖鎖の機能 を理解するための重要な手掛かりを得ることになる。しかし 
nature. However, the extensive complexity and heterogeneity of most natural ligand glycan structures prevent closer investigation of the mechanism underlying the recognition in detail. New advanced technologies for glycochemistry to synthesize glycans with sophisticated structures in reasonable amounts are imperative in the further pursuit of this issue. In this respect, it would be interesting if a series of structural MLO mimics are chemically synthesized and then the interaction of these compounds with MBP can be investigated by high-resolution NMR or X-ray crystallography. Hopefully, we may be able to obtain more detailed knowledge on the unique topology of fucose residues in the tandem repeat structures of the $\mathrm{Le}^{\mathrm{a}}$ epitope in solution and also those in the MBP-ligands complex.

On the other hand, it has become clearer and clearer that some C-type lectins such as MBP and DC-SIGN (45, 46) recognize certain types of human tumor cells. It may be reasonable to assume that these lectins or modifications of them may have potential clinical use as novel cancer diagnostic and therapeutic agents for cancer patients. In addition, antibodies raised against these lectin ligands may be useful as well for the same purpose. Chemically synthesized structural MLO mimics may serve as antigens or haptens to raise antibodies that recognize tumor cells, and also as a tumor vaccine.

\section{Acknowledgements}

The authors are grateful to Dr. Kay-Hooi Khoo of Academia Sinica, Taipei, Taiwan, for the mass spectrometry analyses of the glycans and glycopeptides, Dr. Nana Kawasaki of the National Institute of Health Science, Tokyo, for identification of proteins by LC-MS/MS, Dr. Toshihiko Sawada of Gifu University, Gifu, for 3D modeling of tandem repeats of the Le $\mathrm{e}^{\mathrm{a}}$ unit, and Dr. Masaji Ishiguro of the Suntory Institute for Bioorganic Research, Osaka, for modeling of the MBP-Lewis oligosaccharide complex. The authors also extend their appreciation to all the co-authors of their papers listed in the references, in particular, Drs. Bruce Yong Ma and Motohiro Nonaka, and Ms. Risa Inoue for their respective contributions. The authors also thank Drs. Tomio Kotani, Yatsuki Aratake, and Kazumi Umeki of the University of Miyazaki for preparation of the anti-CD26 mAbs, and Ms. Tomoko Tominaga for the secretarial assistance.

\section{References}

1. Ashwell, G., and Morell, A.G. (1974) Adv. Enzymol. 41, 99-128.

2. Kawasaki, T., and Ashwell, G. (1976) J. Biol. Chem. 251, 1296-1302.

3. Kawasaki, T., and Ashwell, G. (1977) J. Biol. Chem. 252, 6536-6543.

4. Drickamer, K. (1999) Curr. Opin. Struct. Biol. 9, 585-90.

5. Kawasaki, T., Etoh, R., and Yamashina, I. (1978) Biochem. Biophys. Res. Commun. 81,1018-1024.

6. Kozutsumi, Y., Kawasaki, T., and Yamashina, I. (1980) Biochem. Biophys. Res. Commun. 95, 658-664.

7. Sastry, K., Zahedi, K., Lelias, J.M., Whitehead, A.S., and Ezekowitz, R.A. (1991) J. Immunol. 147, 692-697.

8. Drickamer, K., Dordal, M.S., and Reynolds, L. (1986) J. Biol. Chem. 261, 6878-6887.
ながら、一般に、天然のリガンド糖鎖は非常に複雑な構造を 持ち、また、多くの場合不均一性を備えているため、レクチ ンによる認識の詳細なメカニズムの解明を妨げている。一方、 最近の糖鎖合成化学の高度な新技術は、洗練された構造を持 つ糖鎖を然るべき規模で合成することを可能としており、天 然物のもつ欠点を克服しつつ新たな成果をもたらす段階に 入ってきていると思われる。この点、一連の MLO 分子の分子 ミミックを化学合成でき、これらの化合物と MBP との相互作 用を高分解能 NMR やX 線結晶構造解析などにより検討する ことができれば、それは大変興味深いものになると思われる。 うまくいけば、溶液中での $\mathrm{Le}^{\mathrm{a}}$ のタンデム繰り返し構造のフ コース残基のトポロジーに関するより詳細な知識を得ること ができ、MBP との相互作用の詳細を理解できるものと期待し ている。

一方、同じC- 型レクチンの仲間である MBP と DC SIGN は良く似た糖結合性を持っているが、最近、ある種の

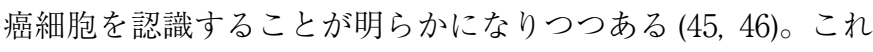
らのレクチンやこれらをシーズとして開発された新規化合物 は新しい癌の診断や治療に利用される可能性がある。また、 レクチンの内在性リガンドに対する抗体は、レクチンと同じ 目的のために有効に利用される可能性がある。化学合成した MLO ミミックは、抗原またはハプテンとして腫瘍細胞を認識 する抗体を産生する手段としてばかりでなく、腫瘍ワクチン の一つの手段として利用される可能もあると考えている。 
9. Mogues, T., Ota, T., Tauber, A.I., and Sastry, K.N. (1996) Glycobiology 6, 543-550.

10. Ma, B.Y., Nakamura, N., Dlabak, V., Naito, H., Yamaguchi, S., Ishikawa, M., Nonaka, M., Ishiguro, M., Kawasaki, N., Oka, S., and Kawasaki. T. (2007) J. Biol. Chem. 282, 12963-12975.

11. Sastry, K., Herman, G.A., Day, L., Deignan, E., Bruns, G., Morton, C.C., and Ezekowitz, R.A. (1989) J. Exp. Med. $170,1175-1189$.

12. Taylor, M.E., Brickell, P.M., Craig, R.K., and Summerfield, J.A. (1989) Biochem. J. 262, 763-771.

13. Kawai, T., Suzuki, Y., Eda, S., Ohtani, K., Kase, T., Fujinaga, Y., Sakamoto, T., Kurimura, T., and Wakamiya, N, (1997) Gene 186, 161165.

14. Kawai, T., Suzuki, Y., Eda, S., Ohtani, K., Kase, T., Sakamoto, T., Uemura, H., and Wakamiya, N. (1998) Glycobiology 8, 237-244.

15. Laursen, S. B., Dalgaard, T.S., Thiel, S., B. L., Lim, T., Jensen, V., Juul-Madsen, H.R., Takahashi, A., Hamana, T., Kawakami, M., and Jensenius J.C. (1998) Immunology 93, 421-430.

16. Kurata, H., Sannoh, T., Kozutsumi, Y., Yokota, Y., and Kawasaki, T. (1994) J. Biochem. 115,1148-1154.

17. Kawasaki, N., Kawasaki, T., and Yamashina, I. (1983) J. Biochem. 94, 937-947.

18. Ikeda, K,. Sannoh, T., Kawasaki, N., Kawasaki, T., and Yamashina, I. (1987) J. Biol. Chem. 262, 7451-7454.

19. Super, M., Thiel, S., Lu, J., Levinsky, R.J., and Turner, M.W. (1989) Lancet 2, 1236-1239.

20. Ohta, M., Okada, M., Yamashina, I., and Kawasaki, T. (1990) J. Biol. Chem. 265, 1980-1984.

21. Lu, J., Thiel, S., and Wiedemann, H. (1990) J. Immunol. 144, 2287-2294.

22. Kawasaki, T. (1999) Biochim. Biophys. Acta 1473, 186-195.

23. Takahashi, K., Ip, W. E., Michelow, I.C., and Ezekowitz, R.A. (2005) Curr. Opin. Immunol.18, 16-23.

24. Dommett, R.M., Klein, N., and Turner, M.W. (2006) Tissue Antigens 68,193-209.

25. Kawasaki, N., Nakagawa, T., and Kawasaki, T. (2005) Book of Gene and Medicine 3, pp.227-233, MEDICAL DO CO. Osaka (in Japanese)

26. Ma, Y., Uemura. K., Oka, S., Kozutsumi, Y., Kawasaki, N., and Kawasaki, T. (1999) Proc. Natl. Acad. Sci. USA. 96, $371-375$.

27. Mori, K., Kawasaki, T., and Yamashina, I. (1984) Arch. Biochem. Biophys. 232, 223-233.

28. Mori, K., Kawasaki, T., and Yamashina, I. (1988) Arch. Biochem. Biophys. 264, 647-656.

29. Nonaka, M., Ma, B.Y., Ohtani, M., Yamamoto, A., Murata, M., Totani, K., Ito Y., Miwa, K., Nogami, W., Kawasaki, N., and Kawasaki, T. (2007) J. Biol. Chem. 282, 17908-17920.

30. Drickamer, K., and Taylor, M.E. (1993) Annu. Rev. Cell Biol. 9, 237-264.

31. Yokota, Y., Arai, Y., and Kawasaki, T. (1995) J. Biochem. 117, 414-419.

32. Mizuno, Y., Kozutsumi, Y., Kawasaki, T., and Yamashina, I. (1981) J. Biol. Chem. 256, 4247-4252.

33. Childs, R. A., Drickamer, K., Kawasaki, T., Thiel, S., Mizuochi, T., and Feizi, T. (1989) Biochem. J. 262, $131-138$.

34. Lee, R.T., Ichikawa,Y., Fay, M., Drickamer, K., Shao, M.C., and Lee, Y.C. (1991) J. Biol. Chem. 266, 4810-4815.

35. Weis, W. I., Drickamer, K., and Hendrickson, W.A. (1992) Nature 360, 127-134

36. Connolly, D.T., Townsend R.R., Kawaguchi, K., Bell, W.R., and Lee, Y.C. (1982) J. Biol. Chem. 257, 939-945.

37. Hoffmann, J.A., Kafatos, F.C., Janeway, C.A., and Ezekowitz, R.A. (1999) Science 284,1313-1318.

38. Ohta, M., and Kawasaki, T. (1994) Glycoconjugate J. 11, 304-308.

39. Muto, S., Sakuma, K., Taniguchi, A., and Matsumoto, K. (1999) Biol. Pharm. Bull. 22, 317-352.

40. Terada, M., Khoo, K.H., Inoue, R., Chen, C.I., Yamada, K., Sakaguchi, H., Kadowaki, N., Ma, B. Y., Oka, S., Kawasaki, T., and Kawasaki. N. (2005) J. Biol. Chem. 280, 10897-10913.

41. Kawasaki, N., Ma, BY., and Kawasaki, T. (2008) in Experimental Glycoscience, Glycobiology (Taniguchi, N., et al. eds.), pp.162-166, Springer Japan, Tokyo.

42. Kawasaki, N., Lin, C.W., Inoue, R., Khoo, K.H., Kawasaki, N., Ma, B.Y., Oka, S., Ishiguro, M., Sawada, T., Ishida, H., Hashimoto, T., and Kawasaki, T. (2009) Glycobiology 19, 437-450.

43. Aertgeerts, K., Ye, S., Shi, L., Prasad, S.G., Witmer, D., Chi, E., Sang, B-C., Wijnands, R. A., Webb, D.R., and Swanson, R.V. (2004) Protein Science 13, 145-154.

44. Kucharzik, T., Lugerinig, A., Yan, Y., Driss, A., Charrier, L., Sitaraman, S., and Merlin, D. (2005) Lab. Invest. 85, $932-941$.

45. van Gisbergen, K.P.J.M., Aarnoudse, C.A., Meijer, G.A., Geijtenbeek, T.B.H., and van Kooyk, Y. (2005) Cancer Res. 65, $5935-5944$.

46. Nonaka, M., Ma, B.Y., Murai, R., Nakamura, N., Baba, M., Kawasaki, N., Hodohara, K., Asano, S., and Kawasaki, T. (2008) J. Immunol. 180, 3347-3356. 


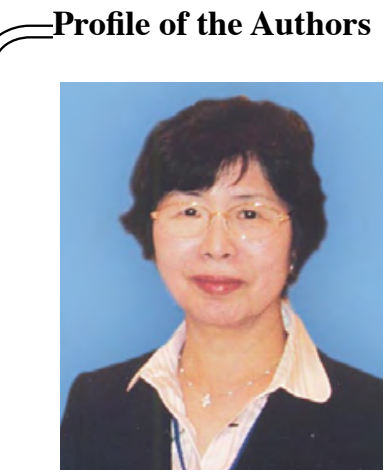

Nobuko Kawasaki graduated from the Department of Biological Chemistry, Faculty of Pharmaceutical Sciences, Kyoto University in 1965, received an MS degree in 1967 and a Ph.D. degree in 1971 from the same Department (Prof. Ikuo Yamashina). 1970 -1977: Assistant Professor at the Department of Medical Chemistry, Kansai Medical University; 1977-1996: Associate Professor, 1996-2003: Professor, at the College of Medical Technology, Kyoto University; 2003-2006: Professor at the School of Health Sciences, Faculty of Medicine, Kyoto University; 2006-present: Visiting Professor at the Research Center for Glycobiotechnology, Ritsumeikan University. Her current research is focused on the structures and functions of endogenous-ligand glycans to an endogenous serum lectin, mannan-binding protein (MBP), in association with anti-tumor activity.

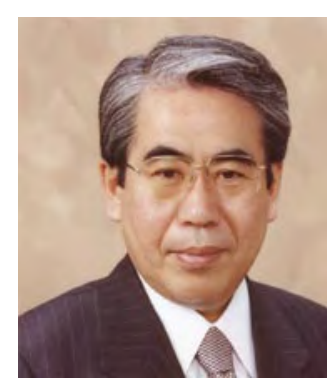

Toshisuke Kawasaki is Director of the Research Center for Glycobiotechnology in Ritsumeikan University and Professor Emeritus of Kyoto University. He graduated from the Department of Biological Chemistry, Faculty of Pharmaceutical Sciences, Kyoto University in 1964, received an MS degree in 1966 and a Ph.D. degree in 1971 from the same department (Prof. Ikuo Yamashina). He worked for the Department of Biological Chemistry, Faculty of Pharmaceutical Sciences, Kyoto University from 1969 to 2005, first as an Assistant Professor (1969-1981), then as a Associate Professor (1981 -1988), and as a Professor (1989-2005). Meanwhile, he worked as a Visiting Fellow in Dr. Gilbert Ashwell's laboratory in NIH (1974-1976). He moved to the present position in 2005 with some of his group members. His current research interest is focused on the roles of mannan-binding protein (MBP) and DC-SIGN in tumor recognition and immune regulation, and on the roles of glycan epitopes in reprogramming and regeneration technologies. 